\title{
Stasis Urin pada Kucing: Evaluasi Klinis dan Laboratoris
}

\section{Urinary Stasis in Cat: Clinical and Laboratory Evaluation}

\author{
Geovani Meryza Oka Putra Caesar ${ }^{1}$, Sitarina Widyarini ${ }^{2}$, Soedarmanto Indarjulianto ${ }^{3 *}$, \\ Alfarisa Nururrozi ${ }^{3}$, Yanuartono ${ }^{3}$, Slamet Raharjo $0^{3}$ \\ ${ }^{1}$ Program Studi Sain Veteriner, Fakultas Kedokteran Hewan, Universitas Gadjah Mada \\ ${ }^{2}$ Departemen Patologi, Fakultas Kedokteran Hewan, Universitas Gadjah Mada \\ ${ }^{3}$ Departemen Ilmu Penyakit Dalam, Fakultas Kedokteran Hewan, Universitas Gadjah Mada \\ *Correponding, author; *Email: indarjulianto@ugm.ac.id
}

Naskah diterima: 18 Desember 2019, direvisi: 3 November 2020, disetujui: 8 Januari 2021

\begin{abstract}
Urinary stasis is a symptom which is usually characterized by the retention of urine and enlarged vesica urinaria (VU). Clinical symptoms and laboratory examination is important to establish the diagnosis of urine stasis. The aim of this study was to evaluate the incidence of urine stasis in cat based on clinically and laboratory examination. Ten (10) male cats that showed clinical symptoms of urination difficulties were used in study. Physically examination in cat was done by examining the general condition and the urinary organs especially VU. Ultrasonography (USG) was used to examine VU condition. Blood sample was taken to examine hematological profile such as total erythrocytes, total leukocytes, hemoglobin and packet cell volume. Result of study demonstrates that 10 cats (100\%) showed clinical symptoms of retention urine more than 24 hours, enlargement VU, distension of VU, lost appetite, weakness and 3 cats $(30 \%)$ experienced the decrease of consciousness. All cats in this study were male, consisting of $8(80 \%)$ 13-24 months- and $2(20 \%)$ more than 24 months old. USG showed wall inflammation in 9 cats $(90 \%)$, thickening of the VU wall in 7 cats $(70 \%)$ and their urolith in 9 cats $(90 \%)$. Hematological test showed the normal blood profile in all cats in this study. To conclude, clinical symptoms of stasis urine is urination difficulties, enlargement and distension of VU. Thickening of the VU wall and the presence of urolith were also found by USG examination. However, blood profile was still in the normal range in all cats in this study.
\end{abstract}

Keywords: cat; FLUTD; ultrasound; urinary stasis; urolith

\begin{abstract}
Abstrak
Stasis urin merupakan diagnosis simtomatif yang menggambarkan tertahannya urin di dalam saluran urinaria yang biasanya ditandai dengan membesarnya vesica urinaria (VU). Gejala klinis dan hasil pemeriksaan laboratoris sangat berperan penting dalam menentukan diagnosa penyakit tersebut. Penelitian ini bertujuan untuk mengevaluasi kejadian stasis urin pada kucing secara klinis dan laboratoris. Materi yang digunakan di dalam penelitian ini adalah 10 ekor kucing yang menunjukkan gejala klinis kesulitan urinasi. Semua kucing diperiksa fisik secara lege artis meliputi kondisi umum dan keadaan organ urinari khususnya VU. Kucing selanjutnya diambil sampel darahnya untuk diperiksa gambaran hematologi meliputi pemeriksaan jumlah eritrosit dan leukosit, nilai hemoglobin ( $\mathrm{Hb})$ dan packet cell volume (PCV). Hasil pemeriksaan pada penelitian ini didapatkan bahwa semua 10 ekor kucing (100\%) menunjukkan gejala klinis tidak urinasi lebih dari 24 jam, pembesaran dan distensi VU, penurunan nafsu makan dan minum, lemas dan 3 ekor kucing (30\%) menunjukkan penurunan reflek kesadaran. Semua
\end{abstract}


kucing dalam penelitian ini berjenis kelamin jantan, terdiri dari 8 ekor (80\%) berumur 13-24 bulan dan 2 ekor (20\%) berumur lebih dari 24 bulan. Hasil pemeriksaan VU menggunakan USG didapatkan adanya peradangan dinding pada 9 ekor (90\%), penebalan dinding pada 7 (70\%) ekor dan adanya urolit pada $9(90 \%)$ ekor kucing. Hasil pemeriksaan hematologi didapatkan semua parameter darah yang diperiksa dalam batasan yang normal. Berdasarkan hasil penelitian ini disimpulkan bahwa stasis urin total menunjukkan gejala klinis tidak urinasi, penurunan nafsu makan, pembesaran dan distensi VU yang pada pemeriksaan menggunakan USG menunjukkan adanya keradangan dan penebalan dinding VU dan ditemukan urolit, serta gambaran darah yang normal.

Kata kunci: FLUTD; kucing; Stasis urin; Urolit; USG

\section{Pendahuluan}

Stasis urin merupakan keadaan yang menggambarkan tertahannya urin di dalam saluran urinaria yang biasanya ditandai dengan membesarnya VU yang terisi urin penuh. Kejadian ini dapat disebabkan adanya kistik kalkuli, infeksi bakteri saluran kemih, peradangan, neoplasia dan penyakit neurogenik. Stasis urin biasanya menjadi salah satu gejala klinis dari Feline Lower Urinary Tract Disease (FLUTD) yang merupakan masalah terutama pada kucing jantan (Tariq et al., 2014; Apritya et al., 2017). Prevalensi kejadian FLUTD telah dilaporkan oleh Forrester and Towell (2015) sebesar 27-72 \%. Gangguan urinaria ini kebanyakan dikarenakan faktor stres, managemen pakan dan juga akibat adanya pola aktivitas kucing (Chew et al., 2011). Stasis urin dapat terjadi karena adanya obstruksi di saluran urinari maupun non obstruksi yang dapat disertai maupun tidak disertai infeksi bakteri (Dorsch et al., 2014; Lund et al. 2015; Apritya et al., 2017). Diagnosa kasus stasis urin dapat ditetapkan berdasarkan anamnesis, pemeriksaan klinis dan pemeriksaan labolatoris (Chew et al., 2011).

Kasus FLUTD sering kali dapat dikenali ketika kucing menunjukkan gejala klinis antara lain hematuria, pollakiuria, stranguria, periuria, disuria dan membesarnya VU (Dorsch et al., 2014; Lund et al. 2015; Nururrozi et al., 2020). Pada tahap awal gejala klinis tersebut sering kali tidak dikenali oleh pemiliknya, sehingga gangguan akan menjadi lebih parah. Lew-Kojrys et al. (2017) melaporkan kejadian gangguan urinasi pada kucing menunjukkan gejala klinis antara lain terjadi stasis urin dan mengalami hematuria. Faktor predisposisi terjadinya stasis urin antara lain jenis kelamin, umur dewasa, dan pemberian pakan kering dengan air minum yang terbatas dalam waktu yang lama (Chew et al., 2011; Lew-Kojrys et al., 2017; Nururrozi et al., 2019). Sebagian besar kasus stasis urin non obstruksi, umumnya akan sembuh dalam beberapa hari tanpa diberi terapi, akan tetapi kejadian stasis urin dapat kembali berulang dalam satu atau dua tahun berikutnya (Forrester and Towell, 2015). Kasus stasis urin yang bersifat obstruktif, biasanya penyumbatan terjadi pada uretra yang mengakibatkan terjadinya retensi urin, dan jika tidak segera ditangani dapat mengakibatkan kematian pada kucing. Kejadian gangguan urinaria yang bersifat obstruksi dengan adanya sumbatan di uretra membuat kucing tidak dapat urinasi dan menunjukan gejala klinis abnormalitas dalam urinasi (Nururrozi et al., 2019).

Selain gejala klinis yang tampak akibat gangguan urinaria, perubahan juga terjadi pada gambaran darah. Tariq et al. (2014) melaporkan bahwa FLUTD juga akan membuat perubahan gambaran darah terutama pada kasus infeksi saluran urinaria yang menyebabkan leukosit meningkat. Pada kasus stasis urin, kucing akan menahan rasa sakit akibat tidak dapat urinasi. Hal ini akan membuat kucing menjadi stres yang dapat membuat perubahan pada nilai leukosit (Salasia dan Hariono, 2010).

Problem atau gangguan sistem urinari pada kucing di Indonesia banyak dijumpai oleh dokter hewan praktisi hewan kesayangan. Menurut Apritya et al., (2017) kejadian kasus FLUTD, cukup tinggi, tetapi laporan tentang stasis urin belum banyak ditemukan. Penelitian ini bertujuan untuk mengevaluasi kejadian stasis urin pada kucing. 


\section{Materi dan Metode}

Materi yang digunakan di dalam penelitian ini adalah 10 ekor kucing berbagai umur dan jenis kelamin yang menunjukkan gejala klinis kesulitan urinasi. Kucing tersebut merupakan pasien yang diperiksakan ke Departemen Ilmu Penyakit Dalam FKH-UGM. Semua kucing diperiksa fisik secara lege artis meliputi kondisi umum serta keadaan organ urinaria khususnya VU. Selanjutnya VU diperiksa menggunakan ultrasonography dengan materi yang diamati adalah perubahan bentuk, ukuran, letak dan echogenisitas. Kucing, selanjutnya diambil sampel darahnya melaui vena chepalica untuk diperiksa gambaran hematologi meliputi pemeriksaan jumlah eritrosit dan leukosit serta nilai $\mathrm{Hb}$ dan PCV (Gandasoebrata, 2007; Salasia dan Hariono, 2010). Data hasil pemeriksaan fisik dan laboratorik selanjutnya dianalisis secara deskriptif.

Penelitian ini telah mendapat izin kelayakan oleh komisi etik Fakultas Kedokteran Hewan, Universitas Gadjah Mada dengan nomer 0100/ EC-FKH/Int./2019.

\section{Hasil dan Pembahasan}

Gejala klinis merupakan skrining awal sebagai dasar penentuan diagnosis suatu penyakit, termasuk gangguan urinasi. Gejala klinis utama pada penelitian ini adalah semua 10 ekor kucing $(100 \%)$ tidak dapat urinasi, mengalami penurunan nafsu makan dan minum, lemas dan 3 ekor (30\%) menunjukkan penurunan reflek kesadaran (Tabel 1). Hasil penelitian Fauziah (2015) dan LewKojrys et al., (2017) menunjukkan bahwa kucing penderita stasis urin menampakkan gejala klinis antara lain depresi, lemah, muntah, nafsu makan menurun, adanya sumbatan, uremia, hematuria, polliuria, periuria merupakan urinasi tidak pada tempatnya, sering menjilati daerah genital dan kesakitan ketika urinasi. Menurunnya/hilangnya nafsu makan kucing penderita stasis urin pada penelitian ini kemungkinan karena terjadi obstruksi pada saluran urinaria (urethra) dan tertahannya urin di dalam VU, yang mengakibatkan rasa sakit dan rasa tidak nyaman.

Problem pada saluran urinasi bagian bawah biasanya ditandai dengan kesulitan urinasi. Sebanyak 10 ekor kucing yang dipakai sebagai sampel di dalam penelitian ini menunjukkan gejala klinis tidak urinasi selama minimal 24 jam. Kucing penderita tersebut semuanya jantan, terdiri dari 8 ekor berumur 13-24 bulan dan 2 ekor berumur lebih dari 24 bulan (Tabel 1). Hasil penelitian yang menunjukkan kucing tidak urinasi ini hampir sama dengan penelitian yang dilakukan oleh LewKojrys et al., (2017) yaitu sebanyak 75\% dari 385 sampel kucing yang mengalami problem urinasi menunjukkan gejala pollakiuria (frekuensi urinasi meningkat dengan volume sedikit) dan disuria (kesulitan atau tidak dapat urinasi). Semua sampel yang dipakai di dalam penelitian ini mengalami problem urinasi dalam keadaan obstruksi total yang ditandai VU teraba penuh, tetapi tidak keluar urin ketika VU dipalpasi/ditekan. Kondisi stasis urin ini terjadi kemungkinan akibat adanya obstruksi pada saluran urinaria maupun adanya keradangan pada saluran urinaria yang membuat urin tidak dapat keluar dari VU. Kurangnya pemahaman pemilik tentang gejala awal terjadinya obtruksi VU memungkinkan kucing baru diperiksakan ke dokter hewan setelah kucing tidak dapat urinasi secara total.

Pada penelitian ini stasis urin terjadi pada kucing yang berumur lebih dari 1 tahun, dan kasus tebanyak terjadi pada kucing yang berumur 13-24 bulan, yaitu sebanyak 8 ekor $(80 \%)$ dan kucing umur lebih dari 24 bulan, yaitu sebanyak 2 ekor (20\%). Hasil penelitian Lew-Kojrys et al., (2017) menunjukkan bahwa gangguan urinasi yang

Tabel 1. Jumlah kucing stasis urin yang menunjukkan gejala klinis

\begin{tabular}{|c|c|c|c|c|c|}
\hline \multirow[b]{2}{*}{ Umur } & \multirow[b]{2}{*}{ jumlah sampel } & \multicolumn{4}{|c|}{ Gejala klinis } \\
\hline & & $\begin{array}{c}\text { Tidak } \\
\text { Urinasi }(\%)\end{array}$ & $\begin{array}{c}\text { Nafsu makan } \\
\text { minum turun }(\%)\end{array}$ & Lemas (\%) & $\begin{array}{l}\text { Reflek sadar } \\
\text { menurun (\%) }\end{array}$ \\
\hline $13-24$ bln & 8 & $8(80)$ & $8(80)$ & $8(80)$ & $2(20)$ \\
\hline$>24 \mathrm{bln}$ & 2 & $2(20)$ & $2(20)$ & $2(20)$ & $1(10)$ \\
\hline Jumlah & 10 & $10(100)$ & $10(100)$ & $10(100)$ & $3(30)$ \\
\hline
\end{tabular}


ditandai dengan stasis urin paling banyak dialami oleh kucing dengan umur rata-rata 5,6 tahun. Stasis urin yang terjadi pada semua kucing pada penelitian ini kemungkinan dipicu karena pemberian pakan kering yang tidak diimbangi dengan pemberian air minum yang cukup, walaupun ada kemungkinan penyebab lain terutama pada kucing yang berumur lebih dari 24 bulan. Kasus urolithiasis pada kucing umur dibawah 24 bulan pada penelitian ini kemungkinan terjadi karena diberikan pakan kering terus menurus sejak umur muda. Penelitian LewKojrys et al., (2017) menyebutkan bahwa ganguan urinasi dapat dialami oleh kucing karena beberapa faktor antara lain jenis kelamin, pensterilan, umur, kondisi hewan, dan pola makan. Triakoso (2016) menyampaikan bahwa kandungan pakan juga dapat menyebabkan meningkatnya pembentukan kristal urin yang dapat menimbulkan stasis urin. Kurangnya asupan air merupakan hal yang sangat penting pada kejadian FLUTD, karena kucing membutuhkan asupan air 40-50 ml/kg/ hari. Pakan kaleng atau tipe basah mengandung air sekitar $60-80 \%$ sedangkan pakan kering hanya mengandung air sebanyak 5-10\%, sehingga kucing membutuhkan lebih banyak air minum untuk memenuhi kecukupan air. Kekurangan asupan air (akibat sifat kucing yang minum sedikit), sedikitnya kandungan air dalam pakan kering dan risiko kehilangan air pada kucing yang mengkonsumsi pakan kering akan menyebabkan hewan mengalami dehidrasi dan berisiko menderita FLUTD (Triakoso, 2016). Tingkat kejadian gangguan urinasi pada kucing terhadap risiko infeksi saluran kemih dan neoplasia meningkat seiring bertambahnya usia. Faktor risiko lain dari kejadian stasis urin pada penderita FLUTD adalah berat badan yang berlebihan, aktivitas fisik tingkat rendah, kurungan dalam ruangan dan kotak kotoran yang terlalu kecil untuk hewan (Cameron et al., 2004; Defauw et al., 2011).

Menurut Chew et al., (2011) stasis urin dapat menyebabkan beberapa abnormalitas fungsi organ lain, termasuk ginjal. Menurut Wardani (2014) adanya penyakit saluran kencing yang ditandai dengan stasis urin merupakan faktor potensial penyebab terjadinya penyakit ginjal kronis. Kejadian penyakit ginjal kronis dapat disebabkan akibat tekanan intra renal yang disertai infeksi saluran kemih berulang atau urosepsis yang merupakan faktor dominan sebagai penyebab destruksi parenkim ginjal dan penurunan jumlah populasi nefron yang utuh (Sukandar, 2006). Yanuartono et al., (2017) menyebutkan bahwa pada penyakit ginjal kronis ditandai dengan penurunan atau hilangnya kemampuan ginjal dalam mengeliminasi produk produk tidak terpakai, mengkonsentrasikan urin dan konservasi elektrolit. Produk produk tidak terpakai tersebut bersifat toksik dan terakumulasi dalam aliran darah sehingga terjadi uremia dan azotemia. Penyakit ginjal kronis menunjukan gejala klinis antara lain adalah poliuri, polidipsi, anoreksi, muntah, turunnya berat badan, membrana mukosa pucat, ulserasi mulut halitosis dan kebutaan akut (Yanuartono et al., 2017).

Hasil pemeriksaan VU menggunakaan USG terhadap 10 ekor kucing yang mengalami stasis urin didapatkan adanya keradangan sebanyak 9 ekor (90\%), penebalan dinding VU sebanyak 7 ekor (70\%) dan adanya urolit sebanyak 9 (90\%) ekor (Tabel 2). Hal serupa disampaikan oleh Zaenab (2008), Chew et al., (2011), bahwa hasil pemeriksaan VU kucing yang mengalami gangguan urinari menggunakan USG didapatkan adanya gambaran keradangan dinding, penebalan dinding dan urolit pada VU. Penebalan dan keradangan pada dinding VU dikarenakan adanya perubahan $\mathrm{pH}$ atau adanya urolit yang melukai dinding VU (Chew et al., 2011). Pembentukan kristal dapat terjadi akibat ketidak seimbangan $\mathrm{pH}$ urin, supersaturasi urin, dan adanya ekskresi mineral dari ginjal sebagai promotor urolit (Stevenson, 2002; Westropp et al., 2005; Osborne et al., 2006).

Tabel 2. Jumlah kucing stasis urin yang menegalami perubahan VU pada pemeriksaan USG $(n=10)$

\begin{tabular}{cccc}
\hline Umur & Keradangan dinding VU & Penebalan dinding VU & Urolit di dalam VU \\
\hline $13-24$ bln & 7 & 5 & 7 \\
$>24$ bln & 2 & 2 & 2 \\
\hline Jumlah & $9(90 \%)$ & $9(90 \%)$ & $7(70 \%)$ \\
\hline
\end{tabular}


Tabel 3. Hasil pemeriksaan darah rutin pada 10 sampel kucing yang mengalami stasis urin

\begin{tabular}{lccc}
\hline \multicolumn{1}{c}{ Paramater } & Normal (\%) & Meningkat (\%) & Menurun (\%) \\
\hline Jumlah Eritrosit & $10(100)$ & $0(0)$ & $0(0)$ \\
Jumlah Leukosit & $10(100)$ & $0(0)$ & $0(0)$ \\
Hemoglobin $(\mathrm{Hb})$ & $10(100)$ & $0(0)$ & $0(0)$ \\
Hematokrit $(\mathrm{PCV})$ & $10(100)$ & $0(0)$ & $0(0)$ \\
\hline
\end{tabular}

Guna mendukung pemeriksaan fisik dan memperkuat diagnosa maka dalam penelitian ini dilakukan pemeriksaan darah. Hasil pemeriksaan darah menunjukkan bahwa semua sampel mempunyai jumlah eritrosit dan leukosit serta nilai $\mathrm{Hb}$ dan PCV yang normal (Tabel 3). Hal ini menunjukkan bahwa stasis urin yang terjadi pada kucing pada penelitian ini tidak disertai adanya infeksi bakteri. Beberapa kasus FLUTD yang diikuti infeksi bakteria akan menunjukan peningkatan nilai leukosit beserta deferensialnya (Dorsch et al., 2014; Tariq et al., 2014; Lund et al., 2015; Lew-Kojrys et al., 2017).

\section{Kesimpulan}

Berdasarkan hasil penelitian ini disimpulkan bahwa stasis urin total sebagai berikut:

1. Terjadi terutama pada kucing jantan dengan $80 \%$ berumur $<24$ bln.

2. Gejala klinis utama adalah tidak urinasi, penurunan nafsu makan dan distensi VU.

3. Gambaran USG: keradangan dan penebalan VU dan adanya urolith.

4. Mempunyai gambaran RBC, WBC, Hb, PCV yang normal.

\section{Ucapan Terima kasih}

Terima kasih kepada Departemen Ilmu Penyakit Dalam Fakultas Kedokteran Hewan Universitas Gadjah Mada dan Fakultas Kedokteran Hewan Universitas Gadjah Mada yang telah memberikan fasilitas laboratorium dan pasien.

\section{Daftar Pustaka}

Apritya, D., Yunani, R., dan Widyawati R. (2017). Analisis urin kasus urolithiasis pada kucing tahun 2017 di Surabaya. Agrovet. 6 (1): 82-84.
Tariq, A., Rafique, R., Abbas, S.Y., Khan, M.N., Huma, I., Perveen, S., and Kamran, M. (2014). Feline Lower Urinary Tract Disease (FLUTD) - An Emerging Problem of Recent Era. J Ve. Sci. \& Anim Husb. 2 (3):1-5.

Cameron, M.E., Casey, R.A., and Bradshaw, J.W.S. (2004). A study of environmental and behavioural factors that may be associated with feline idiopathic cystitis. $J$ Small Anim Pract. 45: 144-147.

Chew, D.J., Dibartola, S.P., and Schenck, P.A. (2011). Canine and Feline Nephrology and Urology. USA: Elsevier Saunders.

Defauw, P.A.M., Maele, I.V., Duchateau, L., Polis I.E., Sauders, J.H., and Daminet, S. (2011). Risk Factors and Clinical Presentation of Cats with Feline Idiopathic Cystitis. $\mathrm{J} \mathrm{Fel}$ Med Surg. 13: 967-975.

Dorsch, R., Hartmann K., and Sauter-Louis C. (2014). Feline Lower Urinary Track Disease in a German Cat Population: A retrospective Analysis of Demographic Data. Causes an Clinical Signs. Tierarztliche Praxis Kleintiere. 42(4): 231-9.

Forrester, S.D., and Towell, T.L. (2015). Feline Idiopathic Cystitis. Vet Clin North Am Small Anim Pract. 45 (5): 783-806.

Gandasoebrata. 2007. Penuntun Labiratorium Klinik. Jakarta: Dian Rakyat.

Lew-Kojrys-Kojrys-Kojrys S., Mikulska-Skupien E., Snarska, A., Krystkiewic, W., and Pomianowski, A. (2017). Evaluation of clinical signs and causes of lower urinary tract disease in Polish cats. Veterinarni Medicina, 62, 2017 (07): 386-393.

Lund, H.S., Krontveit, R.I., Halvorsen, I., and Eggertsdottir, A.V. (2013). Evaluation of Urinalysis from Untreated Adult Cat with 
Lower Urinary Tract Disease and Healthy Control Cat: predictive ability and clinical relevance. J Fel Med Surg.. 15(12): 1086-97.

Lund, H.S., Saevik, B.K., Fisntad, O. W., Grontvedt, E.T., Vatne, T. (2015). Risk Factor for Idiopathic Cystitis in Norwegian Cats: a Matched Case-Control Study. $J$ Fel Med Surg. 1-9.

Nururrozi, A., Soedarmanto, I., Yanuartono, Purnamaningsih, H., Widyarini, S., Raharjo, S., dan Ramandani, D. (2019). Terapi Ammonium Khlorida-Asam Askorbat untuk Menurunkan Tingkat Keasaman Urin dan Kristalisasi Struvit pada Kucing Urolithiasis. J Vet. 20 (1): 8-13.

Nururrozi, A., Yanuartono, Y., Sivananthan, P., dan Indarjulianto, S. (2020) Evaluation of lower urinary tract disease in the Yogyakarta cat population, Indonesia, Vet World. 13(6): 1182-1186.

Osborne, C.A., Bartges, J.W., and Luich, J.P. (2006). Canine and feline urolithiasis: relationship of etiopathogenesis to treatment and prevention. Dalam: Canine and Feline Nephrology and Urology. Osborne CA \& Finco DR (eds.). Lea \& Febiger: Pages: 798-888

Salasia, S.I.O. dan Hariono, B. (2010). Patologi Klinik Veteriner Kasus Patologi Klinis. Yogyakarta: Penerbit Samudra Biru. 18-98.
Stevenson, A. (2002). The Incidence of Urolithiasis in Cats and Dogs and the Influence of Diet in Formation and Prevention of Recurrence. London. Institute of Urology and Nephrology, University College London. 26(2): 169-179.

Sukandar, E. (2006). Nefrologi Klinik. Edisi 3. Bandung: Pusat Informasi Ilmiah Bagian Ilmu Penyakit Dalam Fakultas Kedokteran Unpad. 38:45.

Triakoso. (2019). Pakan dan Kucing. Kesehatan dan Risiko Penyakit Akibat Pakan Pada Kucing. Disampaikan pada Seminar Hill's Nutrition tanggal 21 Mei 2016. 12-15.

Westropp, J.L., Buffington, C.A., and Chew, D. (2005). Feline lower urinary tract disease. Dalam: Textbook of Veterinary Internal Medicine. Ettinger SJ \& Feldman EC (Eds). Saunders. Minnesota chapter 2. 67(4): 731736.

Yanuartono, Nururrozi, A., dan Indarjulianto, S. (2017). Penyakit Ginjal Kronis pada Anjing dan Kucing: Manajemen Terapi dan Diet. JSV. 35 (1):2-17.

Zaenab, S., Noviana, D., dan Zulfanedi, Y. (2008). Ultrasonographic Findings In A Cat With Feline Lower Urinary Tract Disuse. Prosiding KIVNAS 2008. Bogor Indonesia. 325-326. 